\title{
Bulletin of the
}

\section{AUSTRALIAN \\ MATHEMATICAL SOGIETY}

Published for the Australian Mathematical Society

\author{
Editor:John Loxton
}

Volume 105 • Issue 1 • February 2022

\section{CAMBRIDGE}

UNIVERSITY PRESS 


\section{THE AUSTRALIAN MATHEMATICAL SOCIETY}

President: O. Warnaar

Secretary: D. C. Jackson

Treasurer: L. Ferrario

Editor of the Bulletin: John Loxton
School of Mathematics and Physics

The University of Queensland

Brisbane, Queensland 4072, Australia

Department of Mathematics and Statistics

La Trobe University

Bundoora, Victoria 3086, Australia

Mathematical Sciences Institute

The Australian National University

Canberra ACT 0200, Australia

Emeritus Professor

Macquarie University

Macquarie Park 2019, NSW, Australia

\section{ASSOCIATE EDITORS}
R. S. Anderssen
M. Hussain
K. L. McAvaney
J. Simpson
J. Cossey
O. D. Jones
B. A. Davey
G. I. Lehrer
J. Grotowski
J. Li
R. Hazrat
R. J. Loy
T. W. Ng
J. Parkinson
P. Portal
J. H. Rubinstein
A. Sims
B. Sims
D. E. Taylor
T. Trudgian

Membership and correspondence: Applications for membership, notices of changes of address or title or position, members' subscriptions and correspondence related to accounts should be sent to the Treasurer. All other correspondence should be sent to the Secretary.

Subscriptions: The Bulletin of the Australian Mathematical Society began publication in 1969. Normally two volumes of three issues are published annually. Subscription prices for 2022 are $£ 483$ (\$882 in USA, Canada and Mexico) which includes print and electronic access. The electronic-only access price for 2022 is $£ 402 / € 450$ ( $\$ 730$ in USA, Canada and Mexico). Single parts cost $£ 93$ (\$169 in USA, Canada and Mexico). Prices include delivery by air where appropriate. EU subscribers who are not registered for VAT should add VAT at their country's rate. VAT registered subscribers should provide their VAT registration number.

Orders, which must be accompanied by payment, should be sent to a subscription agent, bookseller or direct to the publishers: Cambridge University Press, University Printing House, Shaftesbury Road, Cambridge CB2 8BS or, in the USA, Canada and Mexico, Cambridge University Press, Journals Fulfilment Department, 1 Liberty Plaza, Floor 20, New York, NY 10006. Japanese prices are available from Kinokuniya Company Ltd, PO Box 55, Chitose, Tokyo 156, Japan. Periodicals postage is paid at New York, NY and additional mailing offices. POSTMASTER: send address changes in USA, Canada and Mexico to Bulletin of the Australian Mathematical Society, Cambridge University Press, Journals Fulfilment Department, 1 Liberty Plaza, Floor 20, New York, NY 10006.

This journal is included in the Cambridge Core service. Further information, and online access for subscribers, is available at cambridge.org/baz.

Copying: This journal is registered with the Copyright Clearance Center (CCC), 222 Rosewood Drive, Danvers, MA 01923, USA. Organisations in the USA who are registered with the CCC may therefore copy material beyond the limits permitted by sections 107 and 108 of US copyright law subject to payment to CCC of the per-copy fee of $\$ 16.00$. This consent does not extend to multiple copying for promotional and commercial purposes. Code 0004-9727/2022 \$16.00.

Organisations authorised by the Copyright Licensing Agency may also copy material subject to the usual conditions. For all other use, permission should be sought from Cambridge or the American branch of Cambridge University Press.

Published by Cambridge University Press for the Australian Mathematical Publishing Association Incorporated. Printed in the United Kingdom at Bell \& Bain Ltd, Glasgow.

(C) 2022 Australian Mathematical Publishing Association Inc. 